\title{
Myelin basic protein in the cerebrospinal fluid of patients infected with HIV
}

\author{
H.W.Pfister ${ }^{1}$, K.M.Einhäupl ${ }^{1}$, M.Wick ${ }^{2}$, A.Fateh-Moghadam ${ }^{2}$, M.Huber $^{2}$, E.Schielke ${ }^{1}$, F.D.Goebel ${ }^{3}$, A.Matuschke $^{3}$, \\ B.Heinrich ${ }^{3}$, J.R.Bogner ${ }^{3}$, M.Fröschl ${ }^{4}$, W.Pfäfn' ${ }^{5}$, and M.Ackenheil ${ }^{6}$ \\ 'Neurologische Klinik der Universität München, Klinikum Grosshadern, Marchioninistrasse 15, D-8000 München 70. \\ Federal Republic of Germany \\ ${ }^{2}$ Institut für Klinische Chemie, ${ }^{3}$ Medizinische Poliklinik, ${ }^{4}$ Dermatologische Klinik, ${ }^{5}$ Augenklinik Harlaching, ${ }^{6}$ Psychiatrische Klinik. \\ Ludwig-Maximilians-Universităt, D-8000 München, Federal Republic of Germany
}

\begin{abstract}
Summary. The major pathological abnormalities of HIV encephalopathy are infiltrates of macrophages, multinucleated giant cells, microglial nodules and demyelination. Elevated myelin basic protein (MBP) levels in the cerebrospinal fluid (CSF) provide a marker for central nervous system demyelination. The purpose of this study was to investigate the possible role of CSF MBP as a useful and early marker for HIV encephalopathy. The CSF of 40 consecutive patients with HIV infection of various clinical stages was investigated, including 13 patients with clinical signs of HIV encephalopathy. CSF MBP was elevated in 2 patients $(5.0$ and $5.3 \mathrm{ng} / \mathrm{ml})$, both of whom had moderate to severe HIV encephalopathy. The course of the disease was rapid in both patients. In the remaining 38 patients, CSF MBP levels were marginally elevated $(n=12)$ or normal $(n=26)$. Our results suggest that CSF MBP is not a sensitive marker for the diagnosis and evaluation of HIV encephalopathy, but may be an indicator of prognosis for the course of the disease. There were only few findings of elevated CSF MBP levels in patients with HIV encephalopathy in the current study, and this may be because the disorder progressed slowly in most patients. It is possible that CSF MBP levels in HIV encephalopathy may only be elevated with acute clinical deterioration but are normal in slowly progressive forms of demyelination, as seen in multiple sclerosis.
\end{abstract}

Key words: Myelin basic protein - AIDS - HIV encephalopathy

\section{Introduction}

Neurological disorders have been reported in approximately $40 \%$ of adult AIDS patients [11, 22]. However, up to $70 \%-$ $80 \%$ of adult AIDS patients have been shown to have neuropathological abnormalities in autopsy-based surveys [14, 19]. The most frequent and most important cause of neurological morbidity in HIV-infected patients is HIV encephalopathy [7]. There is increasing evidence that this disorder, which has also been referred to as subacute encephalitis $[17,19]$ or AIDS dementia complex $[15,16,20]$, is caused by direct HIV brain infection. The white matter and subcortical structures of the

Offprint requests to: $\mathrm{H}$.W. Pfister cerebral hemispheres are most severely involved with relative sparing of the cortex $[8,14,18,19]$. The major pathological abnormalities are infiltrates of macrophages and multinucleated giant cells and microglial nodules. Involvement of the white matter appears either as diffuse leucoencephalopathy with severe loss of myelin or as small paravascular foci of demyelination $[5,8,10,16]$. De la Monte et al. [5] reported demyelination in $44 \%$ of autopsy cases with HIV encephalopathy.

Elevated myelin basic protein (MBP) levels within the cerebrospinal fluid (CSF) provide a marker for central nervous system demyelination, as has been shown in patients with relapsing-remitting multiple sclerosis $[3,13,24]$. The purpose of the present study was to investigate if CSF MBP has a role as a useful and early marker for HIV encephalopathy. We investigated CSF samples of 40 consecutive patients with HIV infection of various clinical stages, including 13 with clinical signs of HIV encephalopathy.

\section{Patients and methods}

Seven of the HIV-positive persons were clinically healthy (stage WR 1), 22 suffered from the lymphadenopathy syndrome or the AIDS-related complex (WR 2-5) and 11 had full-blown AIDS (WR 6). Clinically manifest HIV encephalopathy was diagnosed in 13 patients. Symptoms of mental deterioration $(n=11)$ and/or pontomesencephalic or cerebellar dysfunction $(n=4)$ were used as diagnostic criteria (Table 1). Opportunistic conditions, including both infections and neoplasms, were not evident in these 13 patients with HIV encephalopathy.

CSF and serum samples were collected from $40 \mathrm{HIV}$-positive patients. Oligoclonal IgG bands were detected by isoelectric focusing. The samples were concentrated and run on a polyacrylamide gel at a $\mathrm{pH}$ gradient of 3-9 (Phast-System; Pharmacia, Uppsala, Sweden). The gels were stained with Coomassie blue. The ratio CSF albumin/serum albumin was used as an indicator of blood-CSF-barrier permeability. A commercial ELISA was used to determine IgG antibody titres to HIV. A CSF/serum quotient of IgG-related HIV antibodies above 1.5 was considered to indicate intrathecal production of HIV antibodies [12]. MBP in CSF was determined using a commercial, competitive radioimmunoassay (Biodata; Milan. 
Table 1. Clinical data of $40 \mathrm{HIV}$-infected patients

\begin{tabular}{|c|c|c|c|c|c|c|c|c|}
\hline \multirow[t]{2}{*}{ Patient } & \multicolumn{6}{|c|}{ CSF findings } & \multirow[t]{2}{*}{ Neurological findings } & \multirow[t]{2}{*}{ Neurological diagnosis } \\
\hline & $\begin{array}{l}\text { WR- } \\
\text { stage }\end{array}$ & MBP & Cells/ $\mu \mathrm{l}$ & $\begin{array}{l}\text { Albumin } \\
\text { ratio }\end{array}$ & $\begin{array}{l}\text { Oligoclonal } \\
\text { bands }\end{array}$ & $\begin{array}{l}\text { HIV anti- } \\
\text { body: IgG } \\
\text { ratio }\end{array}$ & & \\
\hline 1. & 1 & 2.2 & 146 & 9.8 & + & 8.6 & Dissociated nystagmus & Neurosyphilis \\
\hline 2. & 1 & 2.8 & 1 & 1.6 & - & 0.1 & Normal & \\
\hline 3. & 1 & 3.0 & 4 & 5.5 & + & 3.1 & Normal & \\
\hline 4. & 1 & 3.0 & 4 & 7.1 & - & ND & Normal & \\
\hline 5. & 1 & 3.1 & 3 & 8.9 & + & ND & Normal & \\
\hline 6. & 1 & 3.7 & 5 & 4.8 & + & 1.1 & Normal & \\
\hline 7. & 1 & 4.1 & 4 & 3.5 & - & 0.8 & Normal & \\
\hline 8. & 2 & 2.7 & 4 & 4.0 & + & 6.3 & Dissociated nystagmus & HIV encephalopathy \\
\hline 9. & 2 & 2.8 & 21 & 3.7 & + & 2.7 & Normal & \\
\hline 10. & 2 & 2.9 & 13 & 5.5 & - & 0.3 & Normal & \\
\hline 11. & 2 & 2.9 & 12 & 3.4 & + & 1.6 & Normal & \\
\hline 12. & 2 & 2.9 & 2 & 4.0 & - & 1.1 & Normal & \\
\hline 13. & 2 & 3.0 & 28 & 6.2 & + & 1.7 & Normal & \\
\hline 14. & 2 & 3.0 & 6 & 2.5 & + & 3.6 & Normal & \\
\hline 15. & 2 & 3.0 & 2 & 3.5 & - & 0.1 & $\begin{array}{l}\text { Horizontal gaze evoked nystagmus } \\
\text { (tranquillizer abuse) }\end{array}$ & $\begin{array}{l}\text { Tranquillizer induced } \\
\text { nystagmus }\end{array}$ \\
\hline 16. & 2 & 3.1 & 5 & 4.5 & + & ND & Horizontal gaze evoked nystagmus & HIV encephalopathy \\
\hline 17. & 2 & 3.7 & ND & 7.9 & + & ND & Normal & \\
\hline 18. & 3 & 2.5 & 3 & 5.2 & + & 1.0 & Peripheral facial palsy right & Aseptic meningitis \\
\hline 19. & 3 & 2.8 & 35 & 7.7 & + & 2.1 & Normal & \\
\hline 20. & 3 & 3.0 & 12 & 5.4 & + & 2.6 & Normal & \\
\hline 21. & 3 & 3.2 & 1 & 2.8 & + & 1.7 & Normal & \\
\hline 22. & 3 & 3.6 & 7 & 5.4 & - & 0.3 & Normal & \\
\hline 23. & 4 & 2.9 & 9 & 7.1 & + & 0.1 & $\begin{array}{l}\text { Spontaneous nystagmus left } \\
\text { and upward, horizontal gaze } \\
\text { evoked nystagmus }\end{array}$ & CNS toxoplasmosis \\
\hline 24. & 5 & 2.3 & 1 & 8.3 & + & 1.9 & $\begin{array}{l}\text { Motor, mental and behavioral } \\
\text { disorder, absent tendon reflexes, } \\
\text { pallhypaesthesia }\end{array}$ & $\begin{array}{l}\text { HIV encephalopathy, } \\
\text { polyneuropathy }\end{array}$ \\
\hline 25. & 5 & 2.4 & 2 & 3.1 & + & ND & Normal & \\
\hline 26. & 5 & 2.7 & 5 & 4.3 & + & 0.9 & Mental disorder & HIV encephalopathy \\
\hline 27. & 5 & 2.9 & 3 & 3.1 & - & 3.5 & Normal & \\
\hline 28. & 5 & 3.1 & 2 & 7.1 & - & 0.3 & $\begin{array}{l}\text { Mental disorder, dissociated } \\
\text { nystagmus, cerebellar ataxia }\end{array}$ & HIV encephalopathy \\
\hline 29. & 5 & 3.7 & 18 & 7.7 & + & 18.4 & $\begin{array}{l}\text { Mental disorder, horizontal } \\
\text { gaze evoked nystagmus }\end{array}$ & HIV encephalopathy \\
\hline 30. & 6 & 2.1 & 12 & 5.5 & - & 0.7 & Normal & \\
\hline 31. & 6 & 3.2 & 20 & 6.8 & + & 1.0 & Mental, behavioral disorder & HIV encephalopathy \\
\hline 32. & 6 & 3.4 & 1 & 6.6 & + & 5.5 & Normal & \\
\hline 33. & 6 & 3.4 & 1 & 6.8 & + & 3.5 & Mental disorder & HIV encephalopathy \\
\hline 34. & 6 & 3.4 & 1 & 5.8 & - & ND & Mental disorder & HIV encephalopathy \\
\hline 35. & 6 & 3.7 & 1 & 4.4 & + & ND & Mental disorder & HIV encephalopathy \\
\hline 36. & 6 & 4.1 & 32 & 9.3 & + & ND & Headache, stiff neck & Cryptococcal meningitis \\
\hline 37. & 6 & 4.3 & 1 & 4.0 & + & 3.8 & $\begin{array}{l}\text { Mental disorder, hyporeflexia, } \\
\text { pallhypaesthesia }\end{array}$ & $\begin{array}{l}\text { HIV encephalopathy, } \\
\text { polyneuropathy }\end{array}$ \\
\hline 38. & 6 & 4.3 & 4 & 3.5 & + & 3.2 & Convergence nystagmus & CNS toxoplasmosis \\
\hline 39. & 6 & 5.0 & 1 & 17.5 & + & 0.3 & Mental disorder & HIV encephalopathy \\
\hline 40. & 6 & 5.3 & 1 & 3.8 & + & 1.8 & $\begin{array}{l}\text { Mental disorder, spastic para- } \\
\text { paresis, urinary incontinence }\end{array}$ & $\begin{array}{l}\text { HIV encephalopathy, } \\
\text { myelopathy }\end{array}$ \\
\hline
\end{tabular}

$\mathrm{ND}=$ Not done

Italy). Fifty microlitres of a histone solution $(2.5 \mathrm{ng} / \mathrm{ml})$ was added to $500 \mu \mathrm{l}$ fresh CSF sample to prevent adhesion. The samples were stored at $-18^{\circ} \mathrm{C}$ until they were analysed. The reference range for MBP in CSF was defined as follows: up to $3.4 \mathrm{ng} / \mathrm{ml}$, normal; $3.4-4.6 \mathrm{ng} / \mathrm{ml}$, marginal; and above $4.6 \mathrm{ng} /$ $\mathrm{ml}$, elevated.

\section{Results}

CSF abnormalities were detected in 32 patients $(80 \%)$ Oligoclonal IgG bands were found in the CSF of 29 patients $(73 \%) ; 18$ of 24 patients with oligoclonal IgG bands in the CSF had evidence of intrathecal HIV antibody production. 
Lymphocytic pleocytosis ranging from 5 to $146 \mathrm{cells} / \mu \mathrm{l}$ was present in 17 patients and an elevated ratio of CSF albumin/ serum albumin $(>7.5)$ in 8 patients.

CSF MBP was elevated in two patients ( 5.0 and $5.3 \mathrm{ng} / \mathrm{ml}$ ), both suffering from full-blown AIDS. One of these patients presented with severe dementia and a history of oesophagitis. The other patient had a history of Pneumocystis carinii pneumonia and presented with moderate dementia and severe myelopathy which could not be attributed to any condition other than HIV infection. Neurological symptoms had progressed rapidly over a few months in both patients. In the remaining 38 patients, CSF MBP levels were marginally elevated $(n=12)$ or normal $(n=26)$. There was no significant correlation between elevated (including marginally elevated) CSF MBP levels and intrathecal HIV antibody production, oligoclonal IgG bands, or lymphocytic pleocytosis (chi-square test, $P>0.05$ ).

\section{Discussion}

Elevated levels of CSF MBP secondary to acute myelin breakdown are present in many patients with active disease of the nervous system, e.g. multiple sclerosis, tranverse myelitis, central pontine myelinolysis $[3,25]$. In the current study elevated MBP CSF levels were detected in only 2 patients, both of whom presented with moderate to severe HIV encephalopathy. In the other 11 patients with HIV encephalopathy as well as in 27 HIV patients without clinically apparent HIV encephalopathy, only marginally elevated or normal MBP levels were found. There was no significant correlation between CSF MBP levels and intrathecal HIV antibody production. Our results suggest that CSF MBP is not a sensitive marker for the diagnosis and evaluation of HIV encephalopathy.

The rapidity of demyelination seems to influence MBP levels in the CSF, as is known from studies in multiple sclerosis $[2,4,13]$. In multiple sclerosis elevated MBP was usually detected in the CSF of patients during acute exacerbations of the disease. MBP was not detected in the CSF of any patient with a slowly progressive form of multiple sclerosis. It was speculated that in slowly progressive demyelination CSF MBP might be degraded by macrophages or proteinases or inactivated by antibodies, thus preventing elevation of MBP $[1,6$, $13,21,23]$. The rare finding of elevated CSF MBP levels in patients with HIV encephalopathy in the current study may be explained by the fact that the disorder is more often chronically progressive than subacute in its evolution [20]. It must be stressed that in the current study the clinical course of HIV encephalopathy in the 2 patients with elevated CSF MBP levels differed from that of the other patients with HIV encephalopathy in that both suffered rapidly progressive dementia. Since CSF MBP is elevated in acute exacerbations of multiple sclerosis as well as in rapid progressive cases of HIV encephalopathy, we think that an elevated CSF MBP level may be a prognostic marker for the course of HIV encephalopathy.

Previous studies in patients with other neurological diseases have shown that CSF MBP is not a specific marker. Other neurological disorders affecting the CNS in HIV-infected patients, such as progressive multifocal leucoencephalopathy [25] or herpes simplex encephalitis [9], may also cause elevated CSF MBP levels. Furthermore, combinations of HIV encephalopathy and opportunistic infections may occur, which complicate the interpretation of elevated CSF MBP levels.
We conclude that CSF MBP is not a sensitive marker for HIV encephalopathy. The significance of normal and marginally elevated CSF MBP levels with respect to demyelination is unknown. Elevated CSF MBP levels may indicate a rapidly progressive course of HIV encephalopathy provided that other CNS disease is not present.

\section{References}

1. Alvord EC, Hruby S, Shaw CM, Slimp J (1984) Myelin basic protein and its antibodies in the cerebrospinal fluid in experimental allergic encephalomyelitis, multiple sclerosis and other diseases. Prog Clin Biol Res 146:359-363

2. Biber A, Englert D, Dommasch D, Hempel K (1981) Myelin basic protein in cerebrospinal fluid of patients with multiple sclerosis and other neurological diseases. J Neurol 225:231-236

3. Cohen SR, Herndon RM, McKhann GM (1976) Radioimmunoassay of myelin basic protein in spinal fluid. N Engl J Med 295: $1455-1457$

4. Cohen SR, Brooks BR, Herndon RM, McKhann GM (1980) A diagnostic index of active demyelination: myelin basic protein in cerebrospinal fluid. Ann Neurol 8:25-31

5. De la Monte SM. Ho DD. Schooley RT, Hirsch MS, Richardson Jr EP (1987) Subacute encephalomyelitis of AIDS and its relation to HTLV-III infection. Neurology 37:562-569

6. Einstein ER, Csejtey J, Dalal KB (1972) Proteolytic activity and basic protein loss in and around multiple sclerosis plaques: combined biochemical and histochemical observation. J Neurochem $19: 653-662$

7. Felgenhauer K (1987) Another venereal disease with frequent nervous system involvement: neuro-AIDS. J Neurol 234:65-66

8. Gray F. Gherardi R, Scaravilli F (1988) The neuropathology of the acquired immune deficiency syndrome (AIDS). Brain 111: 245-266

9. Jacque C, Delassalle A, Ranurel G, Raoul M, Lesourd B, Legrand JC (1982) Myelin basic protein in CSF and blood. Arch Neurol 39:557-560

10. Kleihues P, Lang W, Burger PC, Budka H, Vogt M, Maurer R. Luthy R, Siegenthaler W (1985) Progressive diffuse leukoencephalopathy in patients with acquired immune deficiency syndrome (AIDS). Acta Neuropathol (Berl) 68:333-339

11. Levy RM. Bredersen DE. Rosenblum ML. (1985) Neurological manifestations of the acquired immunodeficiency syndrome (AIDS): experience at UCSF and review of the literature, J Neurosurg 62:475-495

12. Lüer W. Poser S, Weber T, Jürgens S, Eichenlaub D, Pohle HD. Felgenhauer K (1988) Chronic HIV encephalitis. I. Cerebrospinal fluid diagnosis. Klin Wochenschr 66:21-28

13. Martin-Mondiere C, Jacque C, Delassalle A, Cesaro P, Carydakis C. Degos JD (1987) Cerebrospinal myelin basic protein in multiple sclerosis. Arch Neurol 44:276-278

14. Moskowitz LB, Hensely GT, Chan JC, Gregorios J, Conley FK (1984) The neuropathology of acquired immune deficiency syndrome. Arch Pathol Lab Med 108:867-872

15. Navia BA, Jordan BDJ. Price PRW (1986) The AIDS dementia complex. I. Clinical features. Ann Neurol 19:517-524

16. Navia BA. Cho ES, Petito CK, Price RW (1986) The AIDS dementia complex. II. Neuropathology. Ann Neurol 19:525-535

17. Nielsen SL, Petito CK, Urmacher CD, Posner JB (1984) Subacute encephalitis in acquired immune deficiency syndrome: a postmortem study. Am J Clin Pathol 82:678-682

18. Petito CK (1988) Review of central nervous system pathology in human immunodeficiency virus infection. Ann Neurol 23 [Suppl]: S54-S57

19. Petito CK, Cho ES, Lemann W, Navia BA, Price RW (1986) Neuropathology of acquired immunodeficiency syndrome (AIDS): an autopsy review. J Neuropathol Exp Neurol 45:635-646

20. Price RW, Sidtis J, Rosenblum M (1988) The AIDS dementia complex: some current questions. Ann Neurol 23 [Suppl]:S27\$33 
21. Prineas JW, Kwon EE, Sternberger NH, Lennon VA (1984) The distribution of myelin-associated glycoprotein and myelin basic protein in actively demyelianting multiple slerosis lesions. J Neuroimmunol 6:251-264

22. Snider WD, Simpson DM, Nielsen S, Gold JWM, Metroka CE, Posner JB (1983) Neurological complications of acquired immune deficiency syndrome: analysis of 50 patients. Ann Neurol 14:403418

23. Wajgt A, Gorny M (1983) CSF antibodies to myelin basic protein and to myelin-associated glycoprotein in multiple sclerosis: evidence of the intrathecal production of antibodies. Acta Neurol Scand 68:337-343
24. Whitaker JN, Bashir RM, Chou CHJ, Kibler RF (1980) Antigenic features of myelin basic protein-like material in cerebrospinal fluid. J Immunol 124:1148-1153

25. Whitaker JN, Lisak RP, Bashir RM, Fitch OH, Seyer JM, Krance R, Lawrence JA, Ch'ien LT, O'Sullivan P (1980) Immunoreactive myelin basic protein in the cerebrospinal fluid in neurological disorders. Ann Neurol 7:58-64

Received September 26, 1988 / Received in revised form February 16 1989 / Accepted February 20, 1989 